\title{
The Effect of Complexity and Work Motivation on The Performance of Minor Change-Scale Product Development Projects In Automotive Manufacturing Industry
}

\section{Pengaruh Kompleksitas dan Motivasi Kerja Terhadap Kinerja Proyek Pengembangan Produk Berskala Minor Change di Industri Otomotif Manufaktur}

\author{
Annisa Dewi Akbari ${ }^{1}$, Indah Sepwina Putri \\ ${ }^{1}$ Program Studi Teknik Industri, Jurusan Teknik Industri, Fakuktas Teknologi Industri, Universitas Trisakti \\ Jl. Kyai Tapa No. 1 Grogol, Kota Jakarta Barat, DKI Jakarta, 11440 \\ 2 Program Studi Teknik Industri, Departemen Teknik Industri, Fakultas Teknologi Industri, Universitas Atma \\ Jaya Yogyakarta \\ Jl. Babarsari No. 44 Yogyakarta, 55284 \\ email : annisa.dewi@trisakti.ac.id \\ doi: https://doi.org/10.31315/opsi.v14i2.5332
}

Received: $3^{\text {rd }}$ August 2021; Revised: 20 th August 2021; Accepted: 67th August 2021;

Available online: $21^{\text {st }}$ December 2021; Published regularly: December 2021

\begin{abstract}
The increasing market competition in the Indonesian automotive manufacturing industry requires automotive manufacturing companies to adapt to changes through product development activities. Unfortunately, failure in product development projects is still high. One of the possible key factors of a successful product development project is work motivation. Another factor that is suspected to affect is the complexity of the project. Therefore, this study aims to find the effect of work motivation and project complexity on product development project performance. The research was conducted on 94 members of product development project team in Indonesian automotive manufacturing industry with a minor change scale using purposive sampling. Data was collected through online questionnaire with a response rate of $65.7 \%$ and then analyzed using PLS-SEM. The results of the study showed that project complexity had a positive effect on work motivation and otherwise on project performance. On the other hand, it turns out that work motivation is not proven to affect the performance of product development projects in the automotive manufacturing industry in Indonesia.
\end{abstract}

Keywords: product development, project performance; project complexity; work motivation

\begin{abstract}
ABSTRAK
Meningkatnya persaingan pasar di industri otomotif manufaktur Indonesia mengharuskan perusahaan otomotif manufaktur untuk cepat beradaptasi dengan perubahan melalui kegiatan pengembangan produk. Namun, sangat disayangkan kegagalan dalam proyek pengembangan produk masih tinggi. Salah satu kemungkinan faktor kunci dalam kesuksesan proyek pengembangan produk adalah faktor motivasi kerja. Faktor lain yang juga disinyalir berpengaruh terhadap kesuksesan proyek ialah kompleksitas proyek. Oleh karena itu penelitian ini bertujuan untuk mencari pengaruh motivasi kerja dan kompleksitas proyek terhadap kinerja proyek pengembangan produk. Penelitian dilakukan terhadap 94 anggota tim proyek pengembangan produk di industri otomotif manufaktur Indonesia berskala minor change dengan menggunakan purposive sampling. Pengumpulan data dilakukan melalui bantuan kuesioner secara online dengan tingkat respon sebesar 65,7\% dan kemudian dianalisis menggunakan PLS-SEM. Hasil penelitian menunjukkan bahwa kompleksitas proyek berpengaruh positif terhadap motivasi kerja dan berpengaruh negatif terhadap kinerja proyek. Di sisi lain ternyata motivasi kerja tidak terbukti berpengaruh terhadap kinerja proyek pengembangan produk di industri otomotif manufaktur di Indonesia.
\end{abstract}

Kata Kunci: kinerja proyek; kompleksitas proyek; motivasi kerja; pengembangan produk 


\section{PENDAHULUAN}

Perkembangan industri dan teknologi membuat persaingan produk di pasar otomotif Indonesia semakin meningkat. Keberhasilan perusahaan untuk menghadapi tantangan ini bergantung pada kemampuan mereka untuk mengidentifikasi kebutuhan pelanggan, menciptakan produk dengan cepat, dan memproduksi dengan biaya rendah. Perusahaan seharusnya cepat beradaptasi dengan perubahan yang ada dengan mengikuti kebutuhan pasar melalui kegiatan pengembangan produk. Kegiatan pengembangan produk termasuk dalam aktivitas proyek. Hal ini sesuai dengan definisi proyek yang dijabarkan oleh Project Management Institute (2017), yaitu suatu kegiatan yang bersifat sementara yang dilaksanakan untuk menghasilkan produk dan jasa yang unik. Namun, sangat disayangkan proyek pengembangan produk masih banyak yang gagal. Crawford (1977) dalam Björklund dkk (2007) mengungkapkan tingkat kegagalan pengembangan produk berkisar antara 20 hingga $90 \%$. Bjorklund dkk (2007) merangkum dari berbagai literatur dan menyimpulkan terdapat tiga faktor yang menentukan kesuksesan proyek pengembangan produk, yaitu knowledge, motivation, dan organizational context. Penelitian tentang pengaruh knowledge dan organizational context di proyek pengembangan produk di industri otomotif manufaktur telah dilakukan, yang hasilnya bahwa pada variabel organizational context khususnya keterlibatan middle manager berpengaruh positif terhadap kinerja proyek di industri otomotif manufaktur (Akbari dan Hartono, 2020). Namun, penelitian tersebut belum menganalisis faktor penting lainnya dalam kesuksesan proyek pengembangan produk yaitu motivasi kerja.

Motivasi kerja adalah pendorong kinerja dalam organisasi (Dwivedula dan Bredillet, 2010). Suatu perusahaan mungkin memiliki bahan material, mesin, dan alat produksi yang terbaik, tetapi semua sumber daya ini tidak ada artinya selama tidak digunakan oleh orang yang memiliki motivasi yang tepat (Rajasekar dan Premkumar, 2017). Tingkat antusiasme yang diterapkan di proyek memiliki dampak langsung pada hasil proyek, karena motivasi dapat menginspirasi, mendorong, dan merangsang individu untuk mencapai tujuan bersama melalui kerja tim (Tonya, 2007). Motivasi proyek adalah aspek kunci untuk proyek yang sukses, namun hanya sedikit penelitian yang menjelaskan subjek penting ini (Schmid dan Adams, 2008).

Berbicara mengenai proyek, termasuk proyek pengembangan produk, maka tidak terlepas dari variabel kompleksitas. Kompleksitas merupakan sarana analitik yang mendalam untuk memahami proyek dan menyusun strategi yang mungkin untuk mengatasi masalah (Hartono dkk., 2019). Menurut Project Management Institute (PMI), kompleksitas tidak akan pernah dapat dihilangkan dari proyek, bahkan cenderung semakin besar. Oleh karena itu kompleksitas ini perlu dikelola dengan baik untuk mengurangi risikonya dan mengakses potensi manfaatnya. Hal ini sesuai dengan pendapat Bakhshi dkk (2016) bahwa organisasi hanya dapat mengantisipasi, memahami, dan mengarahkan kompleksitas untuk mencapai kesuksesan proyek. Ketika karyawan melakukan pekerjaan yang kompleks, karyawan mengalami motivasi yang lebih daripada ketika mereka melakukan pekerjaan yang tidak kompleks, dan mereka terangsang untuk mengembangkan ide-ide yang lebih kreatif saat mereka bekerja (Liu, 2016).

Selanjutnya (Akbari dan Hartono, 2020) mengungkapkan bahwa kompleksitas struktural, sosio politik, dan emergent dapat mempengaruhi keberhasilan proyek pengembangan produk di industri otomotif Indonesia, dimana semakin tinggi kompleksitas maka kinerja proyek semakin menurun. Jenis proyek pengembangan produk pada penelitian yang telah dilakukan ditujukan untuk semua jenis proyek otomotif manufaktur Indonesia. Analisis data dilakukan dengan cara menggabungkan semua jenis proyek sehingga tidak bisa diketahui perbedaan hasilnya untuk masing-masing skala proyek. Berdasarkan data dari responden penelitian tercatat bahwa jenis proyek minor change merupakan proyek terbanyak yang dikerjakan perusahaan otomotif, yaitu sebesar $70 \%$. Proyek berskala minor change merupakan proyek dengan perubahan berupa penyegaran eksterior atau interior mobil.

Berdasarkan penjelasan latar belakang di atas, perlu dilakukan penelitian tentang kerangka berpikir dan pengujian secara empiris mengenai hubungan antara motivasi kerja, kompleksitas, serta kinerja proyek dengan rincian yaitu bagaimana hubungan kompleksitas 
dan motivasi kerja, serta bagaimana hubungan motivasi kerja dan kompleksitas terhadap kinerja proyek di perusahaan otomotif manufaktur. Selain itu, kajian ini menganalisis apakah motivasi kerja dapat memediasi hubungan kompleksitas dan kinerja proyek. Sehingga akhir dari penelitian ini dapat memberikan gambaran bagi praktisi maupun akademisi terkait hubungan motivasi kerja, kompleksitas, dan kinerja proyek.

\section{METODE}

\subsection{Formulasi Hipotesis}

Adapun pengembangan hipotesis dalam penelitian ini adalah sebagai berikut:

a. Pengaruh kompleksitas terhadap motivasi kerja

Kompleksitas kerja memiliki pengaruh positif pada motivasi intrinsik di perusahaan IT Korea (Jo dan Lee, 2012). Karyawan yang merasakan kompleksitas pekerjaan yang lebih besar, lebih mungkin untuk termotivasi oleh suasana hati yang positif untuk bekerja dengan cara yang baru dan praktis, dan kemudian akan berusaha untuk kinerja yang lebih baik (Liu, 2016). Berdasarkan penelitian tersebut dapat ditarik hipotesis bahwa kompleksitas juga akan berpengaruh positif terhadap motivasi anggota tim proyek pengembangan produk di otomotif manufaktur Indonesia.

Hipotesis 1: Kompleksitas berpengaruh positif terhadap motivasi kerja.

\section{b. Pengaruh motivasi kerja terhadap kinerja proyek}

Motivasi dapat menginspirasi, mendorong, dan merangsang individu dan tim proyek untuk mencapai prestasi besar (Tonya, 2007). Tingkat motivasi yang diterapkan individu dan/atau tim untuk upaya proyek dapat memengaruhi semua aspek hasil proyek, termasuk dampak langsung terhadap faktor keberhasilan proyek (3 contraints) (Tonya, 2007). Bredillet dan Dwivedula, (2008) mengusulkan sebuah framework tentang pengaruh motivasi intrinsik terhadap keberhasilan proyek dari perspektif anggota tim dengan berdasarkan hasil studi literatur dari ribuan artikel. Oleh karena itu berdasarkan pemaparan dari penelitian sebelumnya maka dapat ditarik hipotesis bahwa motivasi kerja dapat mempengaruhi kinerja proyek pengembangan produk di otomotif manufaktur.

Hipotesis 2: Motivasi kerja berpengaruh positif terhadap kinerja proyek.

\section{c. Pengaruh kompleksitas terhadap kinerja proyek}

Semakin besar kompleksitas yang ditimbulkan oleh suatu proyek, semakin rendah peluang keberhasilan yang akan tercapai (Maylor dkk., 2013). Kompleksitas proyek berhubungan negatif terhadap kinerja proyek pengembangan produk di industri otomotif manufaktur Indonesia (Akbari dan Hartono, 2020). Berdasarkan penelitian di atas maka dapat dibuat hiptotesis bahwa kompleksitas dapat berpengaruh negatif terhadap kinerja proyek di otomotif manufaktur dengan skala proyek minor change.

Hipotesis 3: Kompleksitas berpengaruh negatif terhadap kinerja proyek.

\section{d. Motivasi kerja sebagai variabel mediasi}

Berdasarkan penelitian-penelitian yang telah disebutkan sebelumnya bahwa kompleksitas dan motivasi berpengaruh terhadap kinerja proyek, serta kompleksitas juga berpengaruh terhadap motivasi kerja, maka dapat ditarik hubungan tidak langsung bahwa motivasi kerja dapat menjadi mediasi antara hubungan kompleksitas dan kinerja proyek.

Hipotesis 4: Motivasi kerja memediasi hubungan kompleksitas dan kinerja proyek

Gambar 1 merupakan framework penelitian yang dibangun berdasarkan hipotesis yang telah ditentukan. Sedangkan Tabel 1 menjelaskan definisi operasional untuk masing-masing variabel.

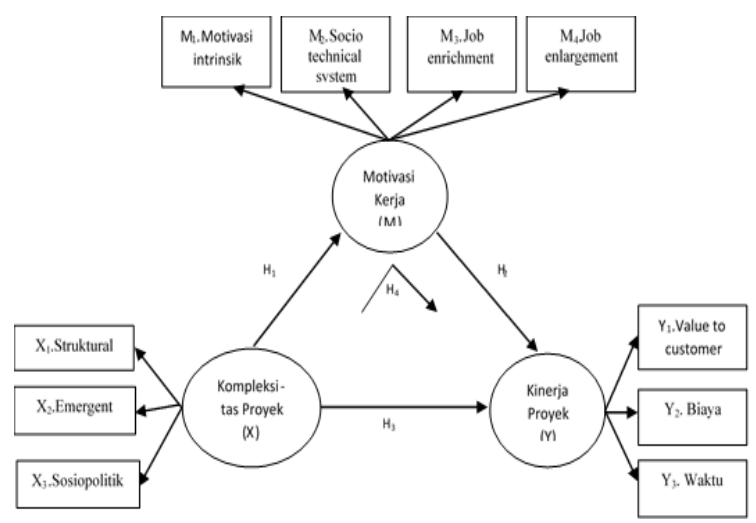

Gambar 1. Framework Penelitian 
Tabel 1. Definisi Operasional Variabel

\begin{tabular}{|c|c|c|}
\hline Variabel & Definisi Operasional & Sub Variabel \\
\hline $\begin{array}{l}\text { Kompleksitas } \\
\text { Proyek }\end{array}$ & $\begin{array}{l}\text { Risiko dalam proyek yang dipengaruhi oleh faktor } \\
\text { persepsi, kesadaran, alam bawah sadar dan afektif } \\
\text { (Maylor dkk., 2013) }\end{array}$ & $\begin{array}{l}\mathrm{X}_{1} . \text { Struktural } \\
\mathrm{X}_{2} \text {. Emergent } \\
\mathrm{X}_{3} \text {. Sosiopolitik } \\
\text { (Maylor dkk., 2013) }\end{array}$ \\
\hline Motivasi kerja & $\begin{array}{l}\text { Proses mengarahkan dorongan dan tindakan batin } \\
\text { seseorang menuju tujuan tertentu dan mengerahkan } \\
\text { energinya untuk mencapai tujuan tersebut. } \\
\text { (Rajasekar dan Premkumar, 2017) }\end{array}$ & $\begin{array}{l}\mathrm{M}_{1} \text {. Intrinsik } \\
\mathrm{M}_{2} . \text { Socio technical system } \\
\mathrm{M}_{3} . \text { Job enrichment } \\
\mathrm{M}_{4 .} \text { Job enlargement } \\
\text { (Dwivedula dan Bredillet, 2010) }\end{array}$ \\
\hline Kinerja Proyek & $\begin{array}{l}\text { Ketepatan dalam waktu, biaya material, tenaga } \\
\text { kerja dan overhead, dan produk dapat memenuhi } \\
\text { kebutuhan dan harapan pelanggan (Hong dkk., } \\
\text { 2011) }\end{array}$ & $\begin{array}{l}\mathrm{Y}_{1} . \text { Value to } \\
\quad \text { customer } \\
\mathrm{Y}_{2 .} \text { Biaya } \\
\mathrm{Y}_{3} \text {. Waktu } \\
\text { (Hong dkk., 2011) }\end{array}$ \\
\hline
\end{tabular}

\subsection{Subjek dan Metode Penelitian}

Unit analisis dalam penelitian ini adalah individu yaitu anggota tim proyek pengembangan produk berskala minor change di perusahaan otomotif manufaktur Indonesia. Pengambilan sampel dilakukan menggunakan metode purposive sampling kepada anggota tim proyek yang telah bergabung minimal di satu siklus penuh sebuah proyek.

Tahap awal dari penelitian ini adalah melakukan tinjauan pustaka berdasarkan penelitian yang sudah ada untuk mengidentifikasi variabel yang mungkin mempengaruhi kesuksesan kinerja proyek. Selanjutnya membangun model teoritis dengan tiga variabel yang telah ditentukan. Variabel motivasi kerja di ukur dengan menggunakan profiling work motivation (Dwivedula dan Bredillet, 2010), sedangkan kompleksitas dan kinerja proyek diukur dengan kuesioner yang pernah digunakan dalam penelitian terkait proyek pengembangan produk (Akbari dan Hartono, 2020). Pengumpulan data dilakukan dengan survei menggunakan kuesioner untuk mengukur motivasi kerja, kompleksitas proyek, dan kinerja proyek.

Pilot studi dilakukan secara kualitatif dan kuantitatif. Sembilan orang responden dilibatkan dalam pilot studi kualitatif untuk validitas konten dan tampilan instrumen penelitian. Hasil dari pilot study kualitatif kemudian digunakan sebagai kuesioner atau instrumen penelitian yang sudah diperbaiki dan digunakan untuk pilot study tahap kedua atau kuantitatif untuk menguji validitas dan reliabilitas instrumen penelitian. Responden pilot studi kuantitatif berjumlah 30 orang yang akhirnya menghasilkan 68 item pernyataan yang valid dan reliabel.

Penyebaran kuesioner dilakukan secara online kepada anggota tim proyek pengembangan produk di perusahaan otomotif manufaktur Indonesia menggunakan link google form dengan respon rate sebesar 65,7\% (115 kuesioner kembali dari 175 kuesioner yang didistribusikan). Setelah dilakukan data cleansing, data yang dianalisis pada tahap selanjutnya berjumlah 94 .

\section{HASIL DAN PEMBAHASAN}

Analisis data dilakukan dengan menggunakan software PLS-SEM dengan tujuan untuk menguji model prediktif. PLS-SEM dapat digunakan untuk kriteria model yang kompleks dan jenis data yang tidak terdistribusi normal.

Evaluasi dilakukan terhadap model outer dan inner pada konstruk first dan second order yang berbentuk reflektif. Evaluasi outer model dilakukan dengan menguji reflective indicator loadings, internal consistency reliability, validitas konvergen dan validitas diskriminan. Nilai indicator loadings yang baik adalah lebih dari 0,7 (Hair dkk., 2019). Sedangkan pengujian internal consistency reliability dapat dinilai dengan melihat composite reliability (CR) dan cronbach's alpha dengan syarat nilainya harus lebih dari 0,6 karena dengan nilai ini menandakan model mempunyai reliabilitas yang tinggi (Hair dkk., 2019). Kriteria yang digunakan untuk menilai validitas konvergen adalah nilai average variance extracted (AVE) harus lebih dari 0,5 (Hair dkk., 2019). Sedangkan pengujian 
Tabel 2. Nilai Validitas dan Reliabilitas

\begin{tabular}{|c|c|c|c|c|c|}
\hline No & Variabel & $\begin{array}{c}\text { Cronbach's } \\
\text { Alpha }\end{array}$ & rho A & $\begin{array}{l}\text { Composite } \\
\text { Reliability }\end{array}$ & AVE \\
\hline & Kompleksitas struktural (X1) & 0.902 & 0.905 & 0.920 & 0.562 \\
\hline & Kompleksitas Sosial Politik (X2) & 0.786 & 0.788 & 0.875 & 0.701 \\
\hline & Kompleksitas Emergent (X3) & 0.932 & 0.933 & 0.941 & 0.573 \\
\hline & Motivasi intrinsik (M1) & 0.725 & 0.730 & 0.845 & 0.644 \\
\hline & Motivasi sosio-technical system (M2) & 0.840 & 0.843 & 0.886 & 0.610 \\
\hline & Kinerja biaya (Y2) & 0.879 & 0.889 & 0.917 & 0.736 \\
\hline & Kinerja waktu (Y3) & 0.725 & 0.827 & 0.874 & 0.777 \\
\hline & Kompleksitas (X) & 0.957 & 0.958 & 0.960 & 0.504 \\
\hline & Motivasi Kerja (M) & 0.866 & 0.870 & 0.896 & 0.519 \\
\hline 10 & Kinerja proyek (Y) & 0.822 & 0.844 & 0.875 & 0.547 \\
\hline
\end{tabular}

validitas diskriminan dilakukan dengan melihat nilai loading dan akar kuadrat AVE pada konstruk yang dituju harus lebih besar dibandingkan dengan konstruk lainnya. Hasil uji validitas dan reliabilitas outermodel ditunjukkan pada Tabel 2 yang menandakan semua syarat sudah terpenuhi.

Setelah analisis outer model selesai, selanjutnya adalah melakukan analisis struktural model atau inner model. Analisis inner model dilakukan dengan menguji kolinearitas dengan melihat nilai variance inflation factor (VIF), menguji koefisien determinasi $\left(\mathrm{R}^{2}\right)$, dan relevansi prediktif $\left(\mathrm{Q}^{2}\right)$. Nilai VIF yang ideal adalah kurang dari 3 (Hair dkk., 2019), yang menunjukkan tidak adanya multikolinearitas. Nilai $\mathrm{R}^{2}$ menunjukkan varians yang dapat dijelaskan dalam suatu konstruk endogen karena pengaruh prediktornya dengan kisaran nilai antara 0 - 1 . Semakin besar nilai $\mathrm{R}^{2}$, maka semakin besar pula kekuatan prediksinya (Hair dkk., 2019). Nilai $Q^{2}$ digunakan untuk mengukur seberapa baik nilai observasi dihasilkan oleh model dan juga estimasi parameternya. Model dikatakan memiliki relevansi prediktif bila memoliki nilai $\mathrm{Q}^{2}$ lebih dari 0 (Hair dkk., 2019).

Tabel 3 menunjukkan nilai VIF untuk setiap variabel yang sudah memenuhi kriteria, sehingga dapat disimpulkan bahwa tidak terdapat multikolinearitas pada model ini.

Tabel 3. Nilai Kolinearitas

\begin{tabular}{lc}
\hline \multicolumn{1}{c}{ Variabel } & Kinerja Proyek (Y) \\
\hline Kompleksitas Proyek (X) & 1.086 \\
Motivasi kerja (M) & 1.086 \\
\hline
\end{tabular}

Selanjutnya nilai $\mathrm{R}^{2}$ dan $\mathrm{Q}^{2}$ ditunjukkan dalam Tabel 4. Analisis terhadap model dalam penelitian ini memperlihatkan daya predikisi yang masih cukup rendah karena nilai R-square untuk variabel kinerja hanya sebesar 10,8\%. Namun hasil ini dapat dimanfaatkan sebagai insight awal tentang variabel yang memberi dampak terhadap kinerja proyek pengembangan produk di industri otomotif manufaktur.

Tabel 4. Nilai $\mathrm{R}^{2}$ dan $\mathrm{Q}^{2}$

\begin{tabular}{clcc}
\hline No & \multicolumn{1}{c}{ Variabel } & $\mathrm{R}^{2}$ & $\mathrm{Q}^{2}$ \\
\hline 1 & Kompleksitas Struktural (X1) & 0.840 & 0,456 \\
2 & Kompleksitas Sosial Politik (X2) & 0.707 & 0,483 \\
3 & Kompleksitas Emergent (X3) & 0.924 & 0,517 \\
4 & Motivasi intrinsik (M1) & 0.744 & 0,462 \\
5 & Motivasi sosio-technical system (M2) & 0.894 & 0,529 \\
6 & Kinerja biaya (Y2) & 0.883 & 0,638 \\
7 & Kinerja waktu (Y3) & 0.453 & 0,310 \\
8 & Motivasi Kerja (M) & 0.079 & 0,033 \\
9 & Kinerja proyek (Y) & 0.108 & 0,051 \\
\hline
\end{tabular}


Setelah dilakukan analisis outer dan inner model, selanjutnya dilakukan pengujian hipotesis. Pengujian hipotesis dilakukan dengan melihat nilai pada path coefficient yang menggambarkan hubungan antar variabel pada signifikansi 0,05 . Nilai path coefficient signifikan apabila $p$-value $<0,05$ dan t hitung lebih dari $\mathrm{t}$ Tabel yang dalam penelitian ini adalah 1,9858 (df=93). Gambar 2 menunjukkan model akhir PLS untuk penelitian ini.

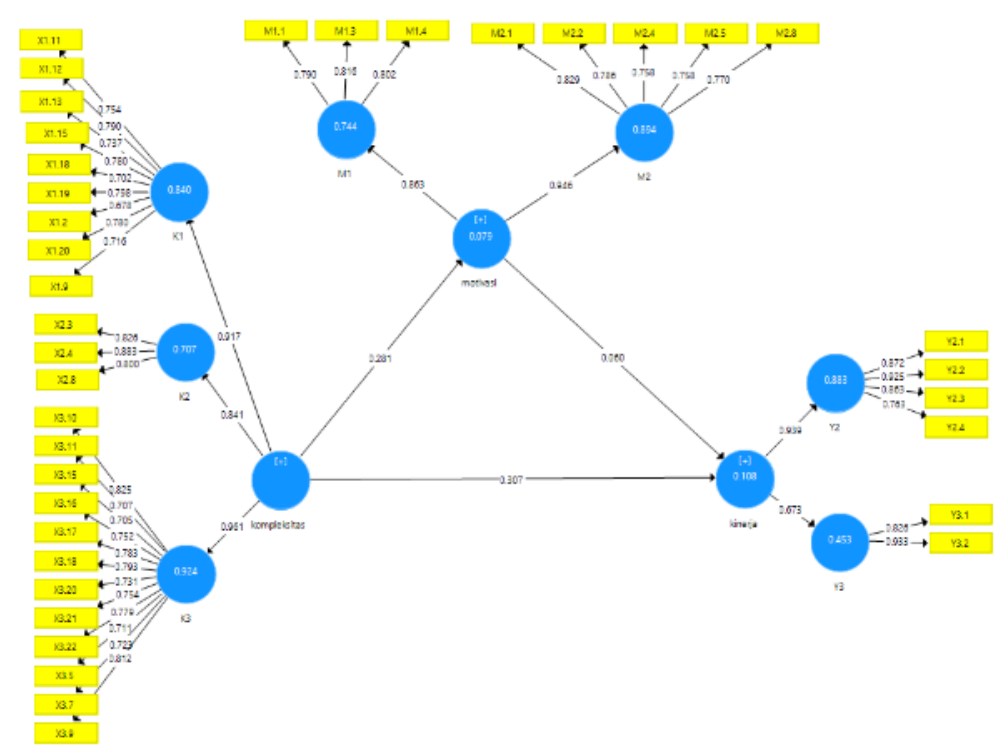

Gambar 2. Model Akhir PLS

Tabel 5. Hasil Path Coefficient

\begin{tabular}{lcccccc}
\hline \multicolumn{1}{c}{ Hipotesis } & Coef & Mean & SD & T & P value & Ket \\
\hline X -> M (H1) & 0,281 & 0,280 & 0,092 & 3,056 & 0,002 & $\sqrt{ }$ \\
M -> Y (H2) & 0,060 & 0,060 & 0,086 & 0,697 & 0,486 & x \\
X - Y (H3) & $-0,307$ & $-0,319$ & 0,112 & 2,732 & 0,007 & $\sqrt{ }$ \\
X -> M -> Y (H4) & 0,017 & 0,016 & 0,026 & 0,641 & 0,522 & x \\
\hline
\end{tabular}

$*$ Keterangan: $\sqrt{ }$ (signifikan), $\mathrm{x}$ (tidak signifikan)

Berdasarkan Tabel 5 diketahui bahwa keputusan uji hipotesis pertama adalah menolak $\mathrm{H}_{0}$ yaitu terdapat cukup bukti bahwa kompleksitas berpengaruh positif terhadap motivasi kerja. Hal ini berarti semakin tinggi kompleksitas, maka dapat meningkatkan motivasi kerja. Hasil dari penelitian ini sudah sesuai dengan hipotesis yang dibangun dan selaras dengan penelitian terdahulu dengan sedikit perbedaan yaitu dalam penelitian ini tidak hanya motivasi intrinsik yang diuji, namun juga motivasi sosio-technical system serta job enrichment \& enlargement. Motivasi intrinsik mengenai kepercayaan dan perasaan bangga atas pencapaian yang dilakukan. Socio-technical system melibatkan pengakuan dari rekan kerja maupun atasan, serta mendapatkan benefit seperti gaji yang sepadan ataupun bonus tahunan. Sedangkan job enrichment dan enlargement menyangkut timbal balik berupa kesempatan kenaikan jabatan. Penelitian ini membuktikan bahwa kompleksitas pekerjaan yang tinggi dapat menambah motivasi kerja anggota tim proyek pengembangan produk di industri otomotif manufaktur.

Hasil dari hipotesis kedua menunjukkan pengaruh yang tidak signifikan antara variabel motivasi kerja dengan kinerja proyek yang artinya tidak ada hubungan antara kedua variabel tersebut. Hasil ini tidak sesuai dengan hipotesis yang dibuat berdasarkan penelitian sebelumnya. Tonya (2007) menyebutkan bahwa motivasi dapat memengaruhi semua aspek hasil proyek, termasuk dampak langsung terhadap faktor keberhasilan proyek. Hal ini didukung juga oleh Bredillet dan Dwivedula, (2008) yang 
membuat framework tentang pengaruh motivasi intrinsik terhadap keberhasilan proyek. Namun pada kenyataannya, hasil penelitian secara kuantitatif menunjukkan hasil yang berbeda, seperti penelitian yang dilakukan oleh Harjono (2015) terhadap karyawan di perusahaan produksi gas Indonesia. Motivasi kerja dan kepemimpinan mempunyai pengaruh terhadap kepuasan kerja namun tidak terhadap kinerja perusahaan (Harjono, 2015). Hasil tersebut selaras dengan penelitian ini yaitu di domain proyek pengembangan produk di industri otomotif manufaktur. Setelah dilakukan konfirmasi kepada praktisi yaitu manajer proyek di salah satu perusahaan otomotif manufaktur Indonesia, hasil ini sangat mungkin terjadi karena perusahaan otomotif manufaktur merupakan perusahaan besar yang mempunyai mother company internasional dan sudah mempunyai standar dalam menjalankan proyek. Anggota tim proyek harus bekerja sesuai tanggung jawab dan perannya.

Hipotesis ketiga dari penelitian ini menunjukkan cukup bukti bahwa kompleksitas berpengaruh negatif terhadap kinerja proyek yang artinya semakin besar kompleksitas maka kinerja proyek semakin menurun. Hal ini selaras dengan penelitian terdahulu yang menunjukkan bahwa semakin besar kompleksitas yang ditimbulkan oleh suatu proyek, semakin rendah peluang keberhasilan yang akan tercapai (Maylor dkk., 2013). Selain itu pada penelitian sebelumnya (Akbari dan hartono, 2020) mengungkapkan bahwa terdapat hubungan yang negatif signifikan antara kompleksitas proyek dengan kinerja proyek pengembangan produk. Perbedaan dari penelitian adalah pada jenis proyek pengembangan produk nya. Penelitian ini dikhususkan untuk proyek minor change yang merupakan proyek yang paling banyak dijalankan di industri manufaktur.

Hipotesis terakhir yaitu mengenai efek mediasi dari variabel motivasi. Hasil menunjukkan nilai yang tidak signifikan sehingga motivasi kerja tidak memediasi hubungan kompleksitas dan kinerja proyek. Menyambung dari karakteristik proyek di perusahaan manufaktur yang sudah mempunyai standar proyek yang baik maka motivasi anggota tim proyek tidak mempengaruhi hubungan kompleksitas proyek dan kinerja.

Berdasarkan hasil pada pembahasan di atas variabel kompleksitas merupakan variabel yang penting untuk kinerja proyek. Brady dan Davies (2014) mengungkapkan bahwa kegagalan mengelola kompleksitas proyek menjadi sebab utama kegagalan proyek untuk memenuhi target yaitu penyelesaian tepat waktu (time), tepat anggaran (cost), dan pemenuhan spesifikasi proyek (quality), sehingga pemahaman tentang kompleksitas penting adanya. Dengan memahami kompleksitas proyek secara benar, manajer proyek akan lebih mampu merumuskan strategi yang dapat mengurangi kompleksitas dan pada akhirnya menurunkan risiko kegagalan proyek (Maylor dan Turner, 2016).

\section{KESIMPULAN}

Model teoritis dari motivasi kerja, kompleksitas, serta kinerja proyek telah berhasil dikembangkan berdasarkan studi literatur dari penelitian sebelumnya. Hasil penelitian ini menunjukkan bahwa kompleksitas sama-sama berpengaruh terhadap motivasi kerja dan kinerja proyek namun dengan pengaruh yang berbeda. Kompleksitas berpengaruh positif terhadap motivasi kerja, namun berkebalikan terhadap kinerja proyek yaitu berpengaruh negatif. Di sisi lain pengaruh antara motivasi kerja dan kinerja proyek tidak signifikan pada penelitian ini sehingga peran variabel mediasi juga tidak terbukti.

Hasil penelitian ini dapat dimanfaatkan perusahaan otomotif manufaktur sebagai insight awal untuk mengelola kompleksitas proyek yang sedang dijalankan agar dapat mencapai kesuksesan kinerja proyek. Salah satu yang dapat dilakukan untuk mengelola kompleksitas adalah dengan memilih dan memilah proyek yang dikerjakan sesuai dengan kapabilitas yang dimiliki serta menetapkan sumber daya yang tepat untuk proyek.

Sedangkan rekomendasi untuk penelitian selanjutnya yaitu peneliti dapat mengeksplor variabel lain yang mungkin dapat berpengaruh terhadap kinerja proyek pengembangan produk. Selain itu penelitian serupa juga dapat dilakukan untuk jenis proyek di sektor lain.

\section{DAFTAR PUSTAKA}

Akbari, A.D., \& Hartono, B. (2020). Pengaruh Knowledge Sharing dan Keterlibatan Middle Manager Terhadap Kinerja Proyek Pengembangan Produk di Industri Otomotif. In Seminar Nasional Teknik 
Industri UGM (pp. TP1-TP6). Yogyakarta, Indonesia: Department of Industrial Engineering, Gadjah Mada University.

Bakhshi, J., Ireland, V., \& Gorod, A. (2016). Clarifying The Project Construct: Past, Present and Future. International Journal Project Management, 34(21), 1199-1213.

Björklund, M., Kalling, T., \& Setterberg, S. (2007). The Success and Failure of New Product Development - A Study With Focus on The Early Phases. Nordic Academy of Management. xxx.

Brady, T. \& Davies, A. (2014) Managing Structural and Dynamic Complexity: a Tale of Two Projects. Project Management Journal, 81, 961-971.

Bredillet, C., \& Dwivedula, R. (2008). The Influence of Work Motivation on Project Success: Towards a framework. In Proceedings of the 8th Annual European Academy of Management (EURAM) Conference.

Ljubljana,

Slovenia: European Academy of Management (EURAM), Belgium.

Dwivedula, R., \& Bredillet, C. (2010). Profiling Work Motivation of Project Workers. International Journal of Project Management, 28(2010), 158-165.

Hair, J.F., Risher, J.J., Sarstedt, M., \& Ringle, C.M. (2019). When to Use and How to Report the Results of PLS-SEM. European Business Review, 31(1), 2-24.

Harjono. (2015). Analisis Pengaruh Motivasi Kerja dan Kepemimpinan Terhadap Kepuasan Kerja Serta Dampaknya Pada Kinerja Perusahaan. Undergraduate Thesis. Universitas Muhammadiyah Gresik..

Hartono, B., Sulistyo, S.R., Chai, K.H., \& Indarti, N. (2019). Knowledge Management Maturity and Performance in a Project Environment: Moderating Roles of Firm Size and Project Complexity. Journal of Management in Engineering, 35(6), 1-17.
Hong, P., Doll, W.J., Revilla, E., \& Nahm, A.Y. (2011) Knowledge Sharing and Strategic Fit in Integrated Product Development Proejcts: An Empirical Study. International Journal of Production Economics, 132(2), 186-196.

Jo, N. Y., \& Lee, K. C., (2012). The Effect of Organizational Trust, Task Complexity and Intrinsic Motivation on Employee Creativity: Emphasis on Moderating Effect of Stress. Human Centric Technology and Service in Smart Space, 182, 199-206.

Liu, W. (2016). Effect of Positive Mood and Job Complexity on Employee Creativity and Performance. Social Behaviour and Personality, 44(5), 865-880.

Maylor, H.R., Turner, N.W., \& MurrayWebster, R. (2013). How Hard Can It Be?: Actively Managing Complexity in Technology Projects: The Complexity Assessment Tool Offers A Framework For Articulating, Assessing, and Managing Sources of Complexity in Technology Projects. Research Technology Management, 56(4), 45-51.

Maylor, H., \& Turner, N. (2016). Understand, Reduce, Respond: Project Complexity Management Theory and Practice. International Journal of Operations \& Production Management, 32(8), 10761093.

Project Management Institute. (2017). Project Management Body of Knowledge (PMBOK). $\quad 6^{\text {th }}$ Edition. Project Management Institute Inc.

Rajasekar, D., \& Premkumar, R. (2017). A Study on Motivation Level of Employees in Automobile Industry. International Journal of Mechanical Engineering and Technology, 8(12), 744-749.

Schmid, B., \& Adams, J. (2008). Motivation in Project Management: The Project Manager's Perspective. Project Management Journal, 39(2), 60-71. 